ARTIKEL PENELITIAN

\title{
Hubungan antara hyperlaxity dengan kejadian flat feet pada atlet pencak silat Pelatda DKI Jakarta
}

\author{
Putri Kusuma Wardhani ${ }^{1}$, Diana Agustini P. ${ }^{2}$, Basuki Supartono ${ }^{3}$ \\ 1. Program Studi Sarjana Kedokteran, Fakultas Kedokteran Universitas Pembangunan Nasional \\ "Veteran" Jakarta; 2. Departemen Anatomi, Fakultas Kedokteran Universitas Pembangunan Nasional \\ "Veteran" Jakarta; 3. Lab Stem Cell, Fakultas Kedokteran Universitas Pembangunan Nasional \\ "Veteran" Jakarta
}

Korespondensi: Putri Kusuma Wardhani; alamat e-mail: kusumawardhaniputri@yahoo.com; no.ponsel: 08119915768

\begin{abstract}
Abstrak
Latar Belakang: Cedera berbanding lurus dengan daya tahan atlet. Menurunnya daya tahan atlet disebabkan oleh banyak faktor, salah satunya adalah hyperlaxity. Hyperlaxity adalah kondisi jaringan ikat sendi (ligamen) yang terlalu lentur. Cedera sering terjadi pada olahraga high impact. Pencak Silat termasuk olahraga high impact. High impact dapat berdampak pada kaki yaitu terjadinya flat feet yang merupakan keadaan lengkung longitudinal kaki mengalami penurunan. Menurut teori, salah satu penyebab jangka panjang flat feet adalah hyperlaxity. Tujuan: Mengetahui hubungan antara hyperlaxity dengan kejadian flat feet pada atlet Pencak Silat untuk mengurangi risiko cedera bagi atlet. Metode: Analitik observasional dengan pendekatan cross-sectional pada 54 atlet Pencak Silat dengan kuesioner, score beighton, dan foot print test. Teknik pengambilan sampel menggunakan metode total sampling. Hasil: Uji statistik menunjukan adanya hubungan hyperlaxity dengan kejadian flat feet $p=0,028(p<0,05)$. Kesimpulan: Terdapat hubungan antara hyperlaxity dengan kejadian flat feet pada atlet Pencak Silat Pelatda DKI Jakarta periode 2017-2020.
\end{abstract}

Kata kunci: Flat feet; hyperlaxity; Pencak Silat

\section{Abstract}

Background: Injury proportionally affects athlete endurance. The declining of athletes endurance is known to be caused by many factors, one of which is hyperlaxity. Hyperlaxity is a condition in which the connective tissue joints (ligaments) are too limber. Injuries frequently happen in high impact sports, and Pencak Silat is one of the martial arts that contains high impact condition. High impact sport has an impact to the occurrence of flat feet which is a condition where the longitudinal arch of the leg is decreased. According to the theory, one of the long-term causes of flat feet is hyperlaxity. Objective: to determine the relationship between hyperlaxity and the incidence of flat feet in martial arts athletes determined to reduce the risk of injury to athletes. Methods: Observational analytic study with crosssectional approach on 54 Pencak Silat athletes with questionnaires, beighton scores, and footprint tests. The sampling techniques was using total sampling method. Results: The statistical test shown a hyperlaxity relationship with the incidence of flat feet with $p=0,028(p<0.05)$. Conclusion: There is $a$ correlation of hyperlaxity with the incident of flat feet phenomena in the DKI Jakarta regional martial arts athlete of the 2017-2020 period.

Keywords: Flat feet; hyperlaxity; Pencak Silat 


\section{PENDAHULUAN}

Atlet adalah seseorang yang melakukan latihan dan tetap berlatih guna mendapatkan kekuatan badan, kecepatan, kelincahan, kelenturan, daya tahan, keseimbangan, dan kekuatan dalam mempersiapkan diri sebelum pertandingan dimulai. ${ }^{1}$ Atlet termasuk ke dalam profesi yang diinginkan banyak orang. Atlet dapat mengharumkan nama bangsa lewat keberhasilannya menjadi juara dalam suatu perlombaan olahraga, seperti pada atlet bernama Suci Wulandari yang memiliki sejarah mendapat dua medali emas di Pekan Olahraga Nasional (Pomnas) Makassar tahun 2016 dan kejuaraan Asia Pacific di India. ${ }^{2}$

Menurut Cashmore, prestasi atlet dari suatu kompetisi adalah hasil dari serangkaian proses belajar dan latihan yang dilakukan sebelumnya. ${ }^{3}$ Prestasi itu merupakan penampilan yang ditunjukkan atlet, di mana ditentukan oleh faktor kesegaran jasmani yang meliputi sistem kardiovaskuler-respiratori, daya tahan, kekuatan, kecepatan, power, koordinasi, kelentukan dan kelincahan. Selain itu, faktor yang juga berperan menentukan prestasi atlet adalah faktor struktur tubuh, postur tubuh, gizi, dan lingkungan. ${ }^{4}$

Ukuran antropometrik merupakan pembawaan fisik seseorang dan disebut juga dengan postur tubuh. Ukuran antropometrik dari tubuh seseorang sangat penting, karena menyesuaikan dengan kebutuhan cabang olahraga yang ditekuni. Ukuran antrophometrik dinilai lewat tinggi dan berat badan, panjang lengan, tungkai, lebar bahu, kemampuan gerak, dan lain sebagainya. ${ }^{4}$

Postur tubuh adalah bentuk tubuh atau sikap badan yang terlihat dari ujung rambut sampai ujung kaki. ${ }^{5}$ Postur tubuh dipertahankan oleh jaringan lunak (saraf, otot, ligamen) dan jaringan keras (tulang dan sendi). ${ }^{6}$ Postur tubuh yang baik sangat penting bagi atlet karena postur yang baik membuat tubuh menjadi simetris dan seimbang, sehingga distribusi beban tersebar merata ke seluruh tubuh membuat tubuh menjadi kokoh. Untuk mencapai performa aktivitas olahraga yang optimal, dibutuhkan tubuh yang memiliki kekuatan dan ketahanan yang cukup. Hal yang mempengaruhi performa atlet adalah kekuatan otot, fleksibilitas, daya tahan, keseimbangan koordinasi, serta efisiensi gerakan. ${ }^{7}$

Postur tubuh normal penting bagi atlet dalam aktivitas olahraganya. Performa atlet dipengaruhi oleh adanya kelelahan, di mana akan menurunkan performa kontrol postur tubuh atlet. Kelelahan, baik yang terlokalisasi maupun seluruh tubuh, mempengaruhi postur tubuh perubahan pada kontraksi otot napas dan jantung, pergerakan cairan tubuh, dan pelepasan produk metabolisme serat otot. ${ }^{8}$ Oleh karena itu, adanya kelainan postur dapat 
berdampak bagi pertandingan olahraga. Sejalan dengan keuntungan yang didapat dari olahraga, terdapat risiko terjadinya cedera, terutama pada olahraga kontak. ${ }^{9}$ Salah satu cabang olahraga kontak adalah Pencak Silat.

Pencak Silat salah satu budaya asli bangsa Indonesia, di mana sangat diyakini oleh para pendekarnya dan pakar Pencak Silat bahwa masyarakat Melayu saat itu menciptakan dan mempergunakan ilmu bela diri ini sejak di masa prasejarah. ${ }^{10}$ Pencak Silat merupakan beladiri yang menggunakan lengan dan tungkai. Serangan beladiri dengan tungkai memiliki lebih dari satu teknik. ${ }^{11}$ Olahraga Pencak Silat tidak terlepas dari adanya gerakan yang selanjutnya akan melibatkan berbagai struktur/jaringan pada tubuh manusia, misalnya sendi, otot, discus, dan kapsuloligamenter. Dilihat dari teknikteknik dalam Pencak Silat, maka olahraga ini termasuk olahraga high impact yang berisiko menimbulkan cedera olahraga, seperti penyakit chronic traumatic encephalophaty (CTE) yang dapat timbul pada olahraga high impact, seperti tinju dan rugbi. ${ }^{12}$

Cedera berkaitan dengan daya tahan atlet. Menurunnya daya tahan atlet disebabkan oleh banyak faktor, salah satunya adalah hyperlaxity. Hyperlaxity adalah kondisi sendi yang derajat gerakan translasi permukaannya menjadi luas, disebabkan oleh bertambahnya panjang dan elastisitas jaringan ikat sendi. Pada bahu, hyperlaxity dapat bermanfaat, di mana seseorang dengan hyperlaxity sering menjadi atlet dengan performa tinggi, khususnya pada olahraga melempar dan menggunakan raket. Akan tetapi, hyperlaxity dapat menjadi kerugian berupa ketidakstabilan tubuh jika kemampuan sendi normal gagal mempertahankan stabilitas mekanis. ${ }^{13}$ Selain itu, jika dibiarkan dalam waktu lama, hyperlaxity dapat berdampak pada anatomi kaki, yaitu terjadinya fenomena flat feet. Flat feet adalah kondisi lengkung longitudinal kaki mengalami penurunan atau keruntuhan. ${ }^{14}$ Flat feet menyebabkan kurang berfungsinya sistem pengungkit yang kaku saat kaki meninggalkan pijakan, sehingga menyebabkan keluhan mudah lelah. ${ }^{6}$ Kelelahan tubuh yang menyeluruh dapat mengganggu keseimbangan postural. Perubahan apapun yang terjadi pada strategi keseimbangan tubuh dapat memicu risiko cedera pada struktur ligamen dan otot. ${ }^{15}$

Menurut penelitian Supartono et al., dari 136 peserta pemuda berprestasi, 32 peserta menderita hyperlaxity dan 31 peserta menderita flat feet. ${ }^{6}$ Saya sudah melakukan observasi singkat yaitu prapenelitian dengan melihat atlet Pencak Silat berlatih dan bertemu dengan pelatih Pemusatan Latihan Daerah atau Pelatda DKI Jakarta.

Berdasarkan latar belakang di atas, hyperlaxity pada atlet Pencak Silat dalam jangka panjang akan menyebabkan flat feet yang memungkinkan terjadinya keadaan cedera yang lebih tinggi. Penelitian ini dianggap penting karena dapat memberikan informasi terkait 
hyperlaxity dengan flat feet untuk menjadi bahan pertimbangan apabila ingin mengikuti cabang olahraga bela diri Pencak Silat tapi sudah memiliki masalah hyperlaxity.

\section{METODE}

Jenis penelitian yang digunakan adalah analitik observasional dengan melakukan pengukuran variable independen dan dependen kemudian menganalisis data yang terkumpul untuk mencari hubungan antarvaribel. Pendekatan yang digunakan dalam penelitian ini adalah cross-sectional (potong lintang). Pada desain crosssectional, seluruh variabel pada penelitian diukur dan dikumpulkan pada waktu yang bersamaan untuk dianalisis mengenai hubungan variabel bebas dan terikat. ${ }^{16}$

Populasi dalam penelitian ini adalah semua atlet Pencak Silat Pelatda DKI Jakarta yang memenuhi kriteria inklusi dan berhasil didapat sebanyak 45 orang. Kriteria pada penelitian kali ini adalah semua atlet Pencak Silat pelatda DKI Jakarta periode 2017-2020 yang bersedia menjadi responden dan mengisi kuesioner dengan lengkap.

Teknik pengambilan sampel dari populasi dalam penelitian ini menggunakan metode total sampling. Total sampling merupakan teknik pengambilan sampel yang dilakukan ketika jumlah sampel sama dengan jumlah populasi. Teknik pengambilan sampel ini dipilih karena jumlah populasi kurang dari
100, sehingga seluruh populasi dijadikan sebagai sampel.

Responden yang masuk dalam kriteria inklusi sebanyak 45 orang. Peneliti melakukan penjelasan ulang mengenai penelitian lalu melakukan pengukuran dan perhitungan score beighton untuk hyperlaxity meliputi kelingking, jari jempol tangan, siku, dan lutut dengan menggunakan alat goniometer untuk mengukur derajat yang termasuk ke dalam perhitungan score beighton dan dinyatakan hasil positif apabila lebih dari 4. Selanjutnya, untuk pengukuran derajat arkus pedis dilakukan dengan footprint test, yaitu mencelupkan telapak kaki bersih ke dalam wadah berisi tinta kemudian menjeplakkan di kertas milimeter blok dan mengukurnya dengan penggaris dengan rumus $B \div[A+B+C]$ dan dinyatakan hasil positif jika lebih dari 0,26.

Analisis data meliputi analisis univariat dan bivariat. Analisis univariat bertujuan untuk menjelaskan dan mendeskripsikan karakteristik setiap variabel penelitian, yaitu usia, jenis kelamin, indeks massa tubuh (IMT), dan lama latihan. Analisis bivariat bertujuan untuk mencari hubungan antara variabel bebas dengan variabel terikat. Pada penelitian ini, analisis data menggunakan aplikasi SPSS dengan uji statistik Chi-Square. Uji statistik ChiSquare digunakan ketika variabel independen atau variabel dependen berupa data kategorik tidak berpasangan dan memiliki bentuk tabel $2 \times \mathrm{k}$ dengan syarat sel yang memiliki expected count kurang dari 5 dan maksimal 20\% dari jumlah sel. Analisis bivariat ini digunakan 
untuk menganalisis hubungan antara variabel independen hyperlaxity dan variabel dependen flat feet. ${ }^{11}$

\section{HASIL DAN PEMBAHASAN}

Pada Tabel 1, didapatkan karakteristik sampel penelitian meliputi usia, jenis kelamin, IMT, dan lama latihan. Terdapat 45 atlet sebagai responden dan berdasarkan hasil penelitian diperoleh 45 responden dengan distribusi umur responden terdiri dari 28 responden $(62,2 \%)$ yang berumur 17-20 tahun dan 17 responden (37,8\%) yang berumur 21-24 tahun. Berdasarkan jenis kelamin, responden terdiri dari 18 responden (40\%) berjenis kelamin perempuan dan 27 responden (60\%) berjenis kelamin laki-laki. Berdasarkan IMT, responden terdiri dari 42 responden (93,3\%) dengan IMT normal dan 3 responden (6,7\%) dengan IMT overweight. Berdasarkan lama latihan Pencak Silat, responden terdiri dari 20 responden $(44,4 \%)$ dengan lama latihan 1 5 tahun dan 25 responden $(55,6 \%)$ dengan lama latihan 6-10 tahun.

Tabel 1. Karakteristik atlet pencak silat Pelatda DKI Jakarta $(n=45)$

\begin{tabular}{lll}
\hline Karakteristik & $\mathbf{n}$ & $\%$ \\
\hline Umur (tahun) & & \\
$17-20$ & 28 & 62,2 \\
$21-24$ & 17 & 37,8 \\
Jenis Kelamin & & \\
Perempuan & 18 & 40 \\
Laki-laki & 27 & 60 \\
IMT (kg/m ${ }^{2}$ ) & & \\
Normal & 42 & 93,3 \\
Overweight & 3 & 6,7 \\
Lama pencak & & \\
silat (tahun) & &
\end{tabular}

\begin{tabular}{lll}
$1-5$ & 20 & 44,4 \\
$6-10$ & 25 & 55,6 \\
\hline
\end{tabular}

Berdasarkan Tabel 2, didapatkan responden yang tidak memiliki hyperlaxity sebanyak 13 responden (28,9\%) tidak flat feet, responden yang memiliki hyperlaxity sebanyak 16 responden (35,6\%) tidak flat feet, responden yang tidak memiliki hyperlaxity sebanyak 2 responden (5,3\%) memiliki flat feet, dan responden yang memiliki hyperlaxity sebanyak (31,1\%) memiliki flat feet. Berdasarkan hasil uji ChiSquare didapatkan nilai $p=0,028 \quad(p<0,05)$ yang menunjukan terdapat hubungan antara hyperlaxity dengan kejadian flat feet.

\section{Tabel 2. Hubungan antara hyperlaxity dengan kejadian flat feet pada atlet pencak silat Pelatda DKI Jakarta periode 2017-2020}

\begin{tabular}{|c|c|c|c|c|c|c|c|}
\hline \multirow{3}{*}{$\begin{array}{c}\text { Hyper- } \\
\text { laxity }\end{array}$} & \multicolumn{4}{|c|}{ Flat feet } & & & \\
\hline & \multicolumn{2}{|c|}{ Tidak } & \multicolumn{2}{|c|}{$\mathrm{Ya}$} & \multicolumn{2}{|c|}{ Jumlah } & \multirow[b]{2}{*}{$\begin{array}{c}\text { Nilai } \\
\mathbf{p}\end{array}$} \\
\hline & $n$ & $\%$ & $\mathbf{n}$ & $\%$ & $\mathbf{n}$ & $\%$ & \\
\hline Tidak & 13 & 28,9 & 2 & 5,3 & 15 & 33,3 & \\
\hline Ya & 16 & 35,6 & 14 & 31,1 & 30 & 66,7 & 0,028 \\
\hline Jumlah & 29 & 64,4 & 16 & 35,6 & 45 & 100 & \\
\hline
\end{tabular}

Berdasarkan hasil yang diperoleh dari penelitian ini, diketahui bahwa usia penelitian yang didapat berada pada rentang umur 17-24 tahun, yang mana tergolong usia remaja dan dewasa muda. Menurut penelitian Pfeiffer et al., flat feet biasa muncul pada bayi dan itu normal, sebagian karena "lemak bayi" yang 
menutupi lengkungan yang sedang berkembang dan sebagian karena lengkungan tersebut memang belum sepenuhnya berkembang. ${ }^{17}$ Arkus longitudinal yang membentuk lengkung pada kaki secara natural akan berkembang sejak awal dekade kehidupan, yaitu ketika anak mulai berdiri, flat feet mengacu pada suatu kondisi medis di mana lengkungan kaki rata jika usia sudah bukan golongan bayi. Teori ini berbanding lurus dengan teori Supartono, bahwa hyperlaxity sering terjadi pada anak-anak dan berkurang seiring berjalannya usia maka kelenturan juga akan menurun, tetapi pada kondisi tertentu ligamen bisa tetap lentur. ${ }^{18}$

Hasil penelitian mengenai umur atlet Pencak Silat di Padepokan TMII Jakarta Timur, menunjukkan bahwa rata rata usia yang didapat terbanyak dan termuda adalah usia 17-20 tahun, pada usia 17 tahun sudah terjadi proses penutupan lempeng epifisis, ini masuk ke dalam kriteria inklusi. Karena penutupan lempeng epifisis menunjukkan bahwa postur atlet sudah menetap.

Berdasarkan hasil yang diperoleh dari penelitian ini, diketahui bahwa jenis kelamin laki-laki lebih banyak dari perempuan, yaitu didapati 27 responden untuk laki-laki dan 18 responden untuk perempuan. Hal ini dikarenakan semua populasi atlet yang diambil mayoritas adalah laki-laki, meskipun lebih banyak laki-laki dari pada perempuan persentase kejadian hyperlaxity pada perempuan tetap lebih besar dari pada laki-laki. Hasil ini berbading lurus dengan teori dari penelitian McKeon et al. bahwa dibandingkan populasi orang dewasa umum, populasi wanita muda memiliki persentase hyperlaxity ligamen umum yang lebih tinggi. ${ }^{19}$

Berdasarkan hasil yang diperoleh dari penelitian ini, diketahui bahwa IMT yang didapat adalah 42 responden (93,3\%) dengan IMT normal dan 3 responden (6,7\%) dengan IMT overweight. Cara perhitungan IMT adalah Berat badan (kg) dibagi tinggi badan $\left(\mathrm{m}^{2}\right)$ dan diklasifikasikan menurut klasifikasi Asia Pasifik dengan kategori normal (18,5-22,9 $\left.\mathrm{kg} / \mathrm{m}^{2}\right)$ dan overweight $\left(>23 \mathrm{~kg} / \mathrm{m}^{2}\right)$. Seluruh responden mayoritas memiliki IMT normal, tetapi terdapat 3 orang yang mengalami kelebihan berat badan, dan dari 3 atlet tersebut 2 di antaranya memiliki flat feet. Hasil ini didukung oleh hasil penelitian Mickle et al. bahwa obesitas atau kelebihan berat badan dalam waktu lama dapat memperparah perubahan struktur arkus kaki yang akan menyebabkan terjadianya fenomena flat feet. ${ }^{20}$

Berdasarkan kuesioner yang diperoleh dari penelitian ini, diketahui bahwa lama latihan yang didapatkan adalah bervariasi mulai dari 1 tahun sampai 10 tahun, dengan lama latihan terbanyak pada 25 responden $(55,6 \%)$ adalah sebesar 6-10 tahun. Lama latihan ini dapat berbanding lurus dengan kejadian flat feet terkait hyperlaxity karena bahwa flat feet dapat disebabkan oleh ligamen kaki yang terlalu lentur dan jangka panjang dari hyperlaxity adalah flat feet. ${ }^{14}$ 
Analisis bivariat yang telah dilakukan didapatkan hasil bahwa dari 45 responden yang diteliti terdapat 14 responden $(31,1 \%)$ yang memiliki hyperlaxity dan flat feet. Hasil uji Chi-Square didapatkan nilai $p=0,028 \quad(p<0,05)$ yang menunjukan terdapat hubungan antara hyperlaxity dengan kejadian flat feet pada atlet Pencak Silat Pelatda DKI Jakarta periode 20172020. Hasil ini diperkuat oleh penelitian Supartono et al. di mana terdapat teori menyatakan bahwa flat feet dapat terjadi dengan salah satu faktornya adalah ligamen kaki yang terlalu lentur. ${ }^{6}$ Kondisi ini sering terjadi pada anak-anak. Akan tetapi, dengan bertambahnya usia anak, maka kelenturan tersebut akan menurun dan telapak kaki akan normal. Pada kondisi tertentu, ligamen kaki tetap sangat lentur menyebabkan kaki tetap datar. Pada penelitian ini usia responden 17 tahun keatas dan dianggap bukan anak-anak, menandakan bahwa terjadinya hyperlaxity dan kejadian flat feet ini adalah sebuah kelainan, Hubungan antara keduanya sejalan pula dengan teori dari penelitian Palomo-López et al. yang menyebutkan terdapat dampak negatif pada kualitas hidup yang berkaitan dengan kesehatan kaki yang berkaitan dengan hyperlaxity. ${ }^{21}$ Bagi atlet yang memiliki flat feet, sebaiknya saat latihan dan sehari-hari menggunakan terapi arch support. Arch support didesain untuk mengubah orientasi kaki dan pergelangan kaki dengan saling memperlihatkan satu sama lain fase midstase saat berlari, bertujuan untuk melawan eversi kaki yang berlebihan dan mengembalikan penyelerasan normal seluruh tubuh bagian bawah.

Pada penelitian ini, terdapat 13 responden $(28,9 \%)$ yang tidak hyperlaxity dan tidak flat feet. Ini menandakan bahwa tidak adanya kelainan pada kelenturan berlebih yang disebabkan oleh peningkatan rasio kolagen III (kolagen I + kolagen III) dan mutasi pada molekul nonkolagenous, yaitu tenascin- $X$ dan tidak adanya penurunan arkus yang menyebabkan flat feet akibat dari hyperlaxity maupun faktor lainnya. ${ }^{21}$

Sebanyak 16 responden (35,6\%) memiliki hyperlaxity tetapi tidak memiliki flat feet. Hal ini dapat terjadi karena perbedaan lama latihan dari masing-masing atlet sebab teori menyebutkan jangka panjang dari hyperlaxity adalah flat feet.

Berdasarkan hasil tabulasi silang, sebanyak 2 responden (5,3\%) tidak memiliki hyperlaxity tetapi memiliki flat feet. Dua responden ini memiliki flat feet karena memiliki IMT > 23 atau termasuk ke dalam overweight. Orang yang mengalami kelebihan berat badan terdapat perubahan transmisi kekuatan mekanik dari ekstremitas ke pergelangan kaki akibat pemuatan mekanik yang berlebihan selama berjalan. Keadaan ini dicurigai karena penumpukan lemak pada arkus longitudinal medial yang berlebihan, sehingga menyebabkan peningkatan tekanan pada lengkungan yang menngakibatkan kaki rata. Hal ini sejalan dengan penelitian menurut Tenenbaum et al. yang menilai hubungan antara IMT dan 
jenis kelamin terhadap flat feet. Hasil dari penelitian tersebut menunjukan terdapat hubungan yang signifikan antara peningkatan IMT terhadap flat feet. ${ }^{22}$

Hasil uji statistik Chi-Square diperoleh nilai signifikansi $p=0,028(p<0,05)$ menunjukan secara statistik hyperlaxity dapat menyebabkan flat feet yang dapat disebabkan oleh beberapa faktor, yaitu jangka waktu mengikuti olahraga Pencak Silat dan latihan yang rutin ditambah dengan penambahan jadwal, serta jam latihan apabila adanya perlombaan. Penulis memberikan saran untuk mempersiapkan pemanasan atau stretching dan pendinginan sekitar 15-30 menit untuk atlet yang memiliki hyperlaxity dan flat feet lebih lama dibandingkan atlet normal. Waktu jeda istirahat juga perlu diperhatikan, di mana pada latihan normal sebanyak 5 menit, tetapi untuk atlet flat feet ini sebaiknya diberikan 2 kali waktu normal karena atlet flat feet akan lebih cepat lelah dibandingkan dengan atlet normal.

\section{KESIMPULAN}

Terdapat hubungan antara hyperlaxity dengan kejadian flat feet pada atlet Pencak Silat Pelatda DKI Jakarta Periode 20172020.

\section{DUKUNGAN FINANSIAL}

Penulis tidak memiliki dukungan finansial dari pihak luar dalam penelitian ini.

\section{UCAPAN TERIMA KASIH}

Penulis mengucapkan terimakasih kepada pihak yang telah berpartisipasi membantu mengerjakan penelitian ini hingga selesai.

\section{KONFLIK KEPENTINGAN}

Penulis tidak memiliki konflik kepentingan dalam penelitian ini.

\section{DAFTAR PUSTAKA}

1. Ardini F, Jannah M. Pengaruh Pelatihan Teknik Relaksasi Pernafasan Dalam Terhadap Competitive State Anxiety Pada Atlet UKM Bulu Tangkis Universitas Negeri Surabaya. Jurnal Psikologi Pendidikan [Internet]. 2017 Jun [cited 2020 Sep 8];4(2):1-5. Available from: https://jurnalmahasiswa.unesa.ac.id/index.php/character/article/view/19934/18239

2. Posmetro Padang. Atlet Silat Suci Wulandari, Target Lulus Seleknas dan PON Papua [Internet]. Padang: Posmetro Padang; 2019 [cited 2020 Sep 8]. Available from: https://posmetropadang.co.id/atlet-silat-suci-wulandari-target-lulus-seleknas-dan-pon-papua/

3. Cashmore E. Sport and Exercise Psychology: The Key Concepts. 2nd ed. New York: Routledge; 2008. $528 \mathrm{p}$.

4. Herman S. Psikologi Olahraga. Jakarta: Departemen Pendidikan Nasional; 2000. 
5. Jalajuwita RN, Paskarini I. Hubungan posisi kerja dengan keluhan muskuloskeletal pada unit pengelasan PT. X Bekasi. The Indonesian Journal of Occupational Safety and Health. 2015 Jan 1;4(1):33-42.

6. Supartono B, Ferdianto, Sari RP. Gambaran postur tubuh peserta seleksi kesehatan pemuda berprestasi tahun 2016. In: Adiati EC, editor. Media Informasi RSON Edisi Ketujuh [Internet]. Jakarta: Media Informasi RSON; 2017 [cited 2020 Sep 9]. p. 40-5. Available from: https://www.scribd.com/document/395434187/Majalah-RSON-07

7. Dinç N, Ergin E. The Effect of 8-Week Core Training on Balance, Agility and Explosive Force Performance. Universal Journal of Educational Research. 2019;7(2):550-5.

8. Pau M, Ibba G, Attene G. Fatigue-induced balance impairment in young soccer players. J Athl Train. 2014 Jul-Aug;49(4):454-61.

9. Hrysomallis C. Injury incidence, risk factors and prevention in Australian rules football. Sports Med. 2013 May;43(5):339-54.

10. Elfarabi A. Pengembangan Buku Ajar Teori Dan Praktek Pencak Silat Untuk Mahasiswa IKIP Budi Utomo Malang. J Sport Sci Educ. 2017 Oct;1(1):24-6.

11. Kriswanto ES. Pencak Silat. Yogyakarta: Pustaka Baru Press; 2015. 153 p.

12. Safinia C, Bershad EM, Clark HB, SantaCruz K, Alakbarova N, Suarez JI, et al. Chronic traumatic encephalopathy in athletes involved with high-impact sports. J Vasc Interv Neurol. 2016 Oct;9(2)34-48.

13. Johnson SM, Robinson CM. Shoulder Instability in Patients with Joint Hyperlaxity. J Bone Joint Surg Am. 2010;92(6):1545-57.

14. Atik A, Ozyurek S. Flexible flatfoot. North Clin Istanb. 2014;1(1):57-64.

15. Steinberg N, Eliakim A, Zaav A, Pantanowitz M, Halumi M, Eisenstein T, et al. Postural balance following aerobic fatigue tests: a longitudinal study among young athletes. J Mot Behav. 2016 Jul; $48(4): 332-40$.

16. Hanief YN, Puspodari P, Lusianti S, Apriliyanto A. Profil Kondisi Fisik Atlet Junior Taekwondo Puslatkot Kediri Tahun 2016 Dalam Menghadapi Pekan Olahraga Provinsi (Porprov) Jawa Timur Tahun 2017. Jurnal Kejaora. 2016 Nov;1(2):17-28.

17. Pfeiffer M, Kotz R, Ledl T, Hauser G, Sluga M. Prevalence of flat foot in preschool-aged children. Pediatrics. 2006 Aug;118(2):634-9.

18. Supartono B. Peranan postur tubuh terhadap prestasi atlet [Internet]. Jakarta: Media Informasi RSON; 2016 Feb 4 [cited 2020 Sep 9]. Available from: http://jih.co.id/wpcontent/uploads/2016/02/04-Peranan-PosturTerhadap-Prestasi-Atlet_11.pdf

19. McKeon KE, London DA, Osei DA, Gelberman RH, Goldfarb CA, Boyer MI, et al. Ligamentous hyperlaxity and dorsal wrist ganglions. J Hand Surg Am. 2013 Nov;38(11):2138-43.

20. Mickle KJ, Steele JR, Munro BJ. The feet of overweight and obese young children: are they flat or fat?. Obesity. 2006 Nov;14(11):1949-53.

21. Palomo-López $P$, Becerro-de-Bengoa-Vallejo R, Losa-Iglesias ME, López-López $D$, Rodríguez-Sanz $D$, Romero-Morales $C$, et al. Effect of generalized ligamentous hyperlaxity related of quality of life in the foot: a case controlled study. Rev Assoc Med Bras. 2018 Sep;64(9):819-23. 
22. Tenenbaum S, Hershkovich O, Gordon B, Bruck N, Thein R, Derazne E, et al. Flexible pes planus in adolescents: body mass index, body height, and gender-an epidemiological study. Foot Ankle Int. 2013 Jun;34(6):811-7. 